\title{
PRANATACARA LEARNING: MODELING, MIND MAPPING, E-LEARNING, OR HYBRID LEARNING?
}

\author{
Suwarna Dwijonagoro ${ }^{1^{*}}$ and Suparno Suparno ${ }^{2}$ \\ ${ }^{1}$ Universitas Negeri Yogyakarta, ${ }^{2}$ Universitas Negeri Malang \\ *e-mail: suwarnadr@uny.ac.id
}

\begin{abstract}
This research was aimed to examine the most effective learning model for Pranatacara (Master of Ceremony) course. By having effective learning, the students can master the skills at being a professional Pranatacara. The study used the experimental method with the pretest-posttest nonequivalent group design. Four parallel classes were given learning treatments each with modeling, mind mapping, e-learning, and hybrid learning. The data of the practice test were analyzed by the one-way Anova. The result indicates that there is a significant difference among the learning models. The hybrid learning can be considered as the most effective model to increase the total score, with the effectiveness of $11.58 \%$; followed by modeling (5.58\%); e-learning (4.10\%); and mind mapping (3.54\%) respectively. The hybrid learning was found as the most effective to improve the fluency score, i.e. $14.23 \%$; followed by mind mapping $(8.31 \%)$; modeling $(4.74 \%)$ and e-learning $(4.00 \%)$ respectively. Moreover, there was a significant difference in the effectiveness of vocal exercise. The highest increase in vocal score was through hybrid learning, with $10.85 \%$; followed by modeling (10.09\%); e-learning (4.39); and mind mappling (2.88\%). Therefore, hybrid learning was declared as the most effective for learning Pranatacara courses and on the contraty, the e-learning was found as the most ineffective.
\end{abstract}

Keywords: e-learning, hybrid learning, master of ceremony, mind mapping, modeling, pranatacara

\section{PEMBELAJARAN PRANATACARA: MODELING, MIND MAPPING, E-LEARNING, ATAU HYBRID LEARNING?}

Abstrak: Penelitian ini bertujuan untuk menguji model pembelajaran pranatacara yang paling efektif. Dengan pembelajaran yang efektif, mahasiswa dapat menguasai keterampilan pranatacara profesional. Penelitian menggunakan desain eksperimen nonequivalent group pretest-posttest design. Empat kelas paralel pranatacara masing-masing diberi perlakukan pembelajaran dengan modeling, mind mapping, e-learning, atau hybrid learning. Data hasil tes praktik dianalisis dengan one-way ANOVA. Hasilnya, ada perbedaan significant efektivitas peningkatan nilai total antarmodel perkuliahan. Hybrid learning paling efektif dalam meningkatan nilai total dengan tingkat efektivitas $11.58 \%$; disusul modeling (5.58\%); e-learning (4.10\%); dan mind mapping (3.54\%). Hybrid learning juga paling efektif dalam meningkatan nilai kelancaran, yaitu 14.23\%; disusul mind mapping (8.31\%); modeling (4.74\%) dan e-learning (4.00\%). Ada perbedaan yang significant ditinjau dari olah suara. Efektivitas peningkatan nilai olah suara paling tinggi berada pada hybrid learning $10.85 \%$; disusul modeling (10.09\%); e-learning (4.39) dan mind mappling (2.88\%). Oleh karena ini, hybrid learning dikatakan paling efektif untuk perkuliahan pranatacara, sebaliknya $e$-learning model yang paling tidak efektif.

Kata Kunci: e-learning, hybrid learning, master of ceremony, mind mapping, modeling, pranatacara 


\section{INTRODUCTION}

This research is very important in order to find the best or most effective solutions to the teaching of Pranatacara (Master of Ceremony) course. So far, the problems that have been encountered in Pranatacara are the teaching that runs with the trial and error process without any systematic procedure. The teaching process depends on the lecturer style with model domination and audio visual samples. It makes the learning results not ideal yet. On the other hand, Pranatcara is one of the prominent courses for culture in the Study Program of Javanese Language Education, especially at Universitas Negeri Yogyakarta.

This condition urges that an effective learning model for Pranatacara course should be found. It is the teaching model that can facilitate the students to achieve speaking competency in guiding a Javanese wedding ceremony comprehensively. There will be, at least, two advantages for the students, i.e (1) to master the requirement of pre-service teacher for speaking skills and (2) to support the students' potential for being entrepreneurs of a professional master of ceremony for Javanese wedding.

Nowadays, pranatacara has become a very promising profession. Based on the survey in Yogyakarta (in urban areas only), there are 74 venues as the sites for wedding ceremonies such as hotels, university auditoriums, meeting houses, restaurants, and village halls. As many as 39 places of them $(52.7 \%)$ are considered as productive locations. It means that those 39 venues are often used for marriage, especially on weekends. These data were obtained from the posting on WhatsApp group of PPY (Paguyuban Pranatacara Yogyakarta $=$ Yogyakarta Masters of Ceremony Association) profession of pranatacara keeps growing as business or career opportunity.
The success of pranatacara lectures is greatly determined by two factors, namely fluency and vocal processing. The fluency of speech must also be supported by the mastery of language or literature, good mentality, creative word arrangement, and systematic speech. Meanwhile, the vocal exercise is a determining factor for speech production, which affects vocal quality. The beautiful vocal can make the listeners more comfortable.

The pranatacara lectures have been carried out in various ways and the most frequently used method is modeling. It is directly performed by lecturers by giving explanations and material demonstration (Salisu \& Ransom, 2014). In this method, the lecturer gives some explanation and example (demonstration) of the procedure for carrying out the Javanese wedding ceremony. The lecturers also provide explanation of new information about Pranatacara, and demonstrate pranatacara skills to students. Then, the students have practice activities of trialand-error. According to Salisu \& Ramson (2014), modeling is considered as an effective strategy since students can implement lecturer instructions and imitate the model from their lecturer. In this way, modeling has two advantages, i.e. (1) providing an accurate and meaningful learning experience and (2) students can master skills more easily because they get visual materials to be imitated (Salisu \& Ramson, 2014).

Modeling is carried out by adjusting to the students' initial abilities. Wu, Chen, \& Chen (2017) state that learning with adaptation contributes to significant satisfaction feeling with t-statistics of 2.036 and p-score of 0.047. By having practice of pranatacara, the students will also have self-assessments and class discussions. It creates a more dynamic process of learning with student-centered activities while the lecturer plays the role as a facilitator. 
Another learning model is mind mapping. For the Pranatacara course, this model is done through analyzing the immediate constituent from the material. By having this analysis, the students use a multiple intelligence approach to obtain sub-program and sub-speeches as a guide for practice. The mind mapping can motivate the students (Ziyadi \& Surya, 2017) to think actively, creatively, and to empower their intelligence (Widiana \& Jampel, 2016). It is also useful to develop conceptual schemes, and to assimilate individual thoughts with new knowledge (Aydin, Baysan, \& Aydoğan, 2017) as well as to make constituent of the main agenda that will be spoken in the pranatacara practice. Moreover, mind mapping is very helpful for learners to improve their science skills (Jbeili, 2013) and to overcome problems in learning (Blessing \& Olufunke, 2015).

The other learning model in Pranatacara courses is e-learning. It is an integral part in this current education system. E-learning can be operationally defined as the use, delivery and achievement of learning, training or education electronically (Khan, 2016). With the support of the Internet connection, it can be accessed anytime and anywhere (Souzanzan \& Bagheri, 2017). E-learning has several advantages in case of flexiblity, preciseness, accessiblity and cheapness. It can also enhance collaborative learning so that e-learning is very useful in enriching knowledge but elearning is vulnerability to plagiarism (Almaqtri, 2014). In addition, Ramadhanti \& Yanda, (2017) highlight that e-learning can develop students' interest attention, retention, affection and motivation to learn and students can learn independently with better ambiance as the result on the escalation of learning achievement and language skills (EFL: English as a Foreign Language for students of English in Iran) as well as decreasing students' anxiety. In line with this view, Shahi (2016), agrees that e-learning can reduce anxiety and provide comfort feeling during learning process. Since it uses various media such as images, photos, audio, and videos to become more meaningful and interesting (Lubis, 2018). Farindhni's research (2018) shows the learning outcomes with video can improve learning motivation and its effectiveness. It is also revealed by Low in his research (2017) that the use of elearning also boosts positive perceptions of and attitudes towards learning so that the summative test scores of English get higher. Besides, in the literature course, the application of technology also supports the mastery of language skills (Ahmadi, 2018).

The learning model that combines online and face-to-face learning is called hybrid learning (Klimova \& Kacetl, 2015). The benefit of hybrid learning is to create the learning process to become effective, suitable, motivating, up to date, and oriented to effective communication skills (Ceylan \& Kesici, 2017). It is usually called interpersonal and classical communication where the lecturers can provide materials anytime anywhere with various methods and evaluations (Eshreteh \& Siaj, 2017). In hybrid learning, students can learn flexibly due to the online format and the lecturers can also present extra motivation support during face-to-face classes (Li, Kay, \& Markovich, 2018). Several studies reviewed by Wichadee (2013) indicate that hybrid learning expands the students' competence, involvement and motivation in learning. The research conducted by Ceylan \& Kesici (2017) suggest that hybrid learning contributes significantly to students' abilities until $72 \%$. It means most of the learning competency is influenced by the use of hybrid learning.

Based on the various results of those studies, modeling, mind mapping, elearning, and hybrid learning models provide the advantages and contribution to each learning competency. However, most 
of the studies tend to put the emphasis on theoretical learning while this study focuses on practical learning, i.e. the practice of being a pranatacara (master of ceremony) for Javanese wedding ceremonies. This research aimed to obtain valid information on the effectiveness of modeling, mind mapping, e-learning, and hybrid learning models in learning Pranatacara course as well as to reveal the most effective one for this learning course.

\section{METHOD}

The research was done through experiment with the pretest-posttest nonequivalent group design (Muhson, 2016) as shown in Figure 1. The research subjects consisted of four parallel classes of Pranatacara at the Javanese Language Education Study Program, Universitas Negeri Yogyakarta. The research steps were (1) administering a pre-test of pranatacara practice in the four classes; (2) giving treatment to each class with one lecture model, i.e. lectures with modeling (X1) that consisted of 20 students, mind mapping (X2) with 22 students, e-learning (X3 consisting of 18 students), hybrid learning (X4) involving 15 students, with the treatments being given for 2 months or 8 meetings; and (3) administering a posttest of pranatacara practice to each class.

The independent variable of this study was a learning model consisting of modeling, mind mapping, e-learning, and hybrid learning. The modeling was conducted by giving the students models or examples of practice as a guidance. In the mind mapping model, the students analyzed the immediate constituent of various events for their practice activities of being a pranatacara/master of ceremony for Javanese wedding. The elearning model was implemented online through UNY Computer Center facilities at

http://besmart.uny.ac.id/v2/course/view.ph p?id=1425 Pranatacara. Meanwhile, the hybrid learning was done by combining the e-learning and face-to-face meetings in the classroom.

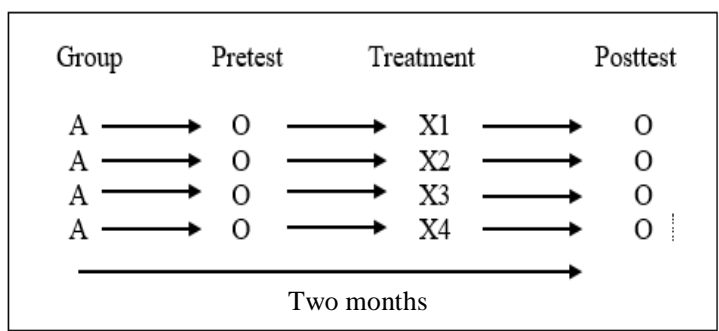

Figure 1. Research Design

The dependent variables in this study are (1) the outcomes of being a pranatacara, (2) speech fluency, and (3) vocal performance. The outcomes of being a pranatacara refers to the total score achieved by the students for their practical testing. It was characterized by the total appearance with indicators of mastery on materials, sound, language, literature, fluency, good order, self-confidence and attitude.

In accordance with the results of the research by Kintu, Zhu, and Kagambe (2017), all subindicators support the total outcome. The speech fluency and vocal exercise were determined as research variables because both of them were important indicators of the students' success in pranatacara practice. Fluency shows mastery of materials, language and literature, systematic way of thinking, and self-confidence. Meanwhile, vocal was very important for a pranatacara because (a) their speech is directly related to the vocal practice, (b) vocal is the main assest for a pranatacara in performing their duties, (c) the beauty of the speech sound was determined by the art of vocal performance, (d) vocal was the first main impression for the audience, (e) the ability of vocal processing is the main indicator for the success of a pranatacara.

The assessment is focused on the total score, fluency indicators, and vocal performance. The researcher compared the outcomes of pre-treatment and posttreatment with those learning models. The 
normality and homogeneity tests were carried out as a prerequisite for testing their effectiveness. Quantitatively, the effectiveness of each model was tested by ANOVA (Muhson, 2016). The result of the analysis is aimed at obtaining the effectivenes of (1) the increase of the total scores among the treatments using the lecturing model, (2) the increase of the scores among the treatments using the lecturing model, and (3) the increase of the total scores of vocal among the four models.

\section{RESULTS AND DISCUSSION Results}

Before being given treatment with the learning model, the class was given a practice test of being pranatacara for Javanese wedding ceremony in Yogyakarta or Surakarta style. The students were free to choose the style. This selection did not affect the assessment because the focus was not on the material. The results are presented in Tables 1 and 2.

Table 1. Statistics for Data Description of Pre-Treatment

\begin{tabular}{llccccc}
\hline \multicolumn{1}{c}{ Variable } & \multicolumn{1}{c}{ Class } & n & Mean & SD & Min & Max \\
\hline Total Score & e-Learning & 18 & 76.17 & 4.950 & 68 & 84 \\
& Modeling & 20 & 78.05 & 4.097 & 72 & 86 \\
& Mind Mapping & 22 & 81.09 & 5.191 & 71 & 88 \\
& Hybrid Learning & 15 & 75.13 & 3.796 & 70 & 82 \\
& Total & 75 & 77.91 & 5.062 & 68 & 88 \\
\hline Fluency Score & e-Learning & 18 & 76.22 & 3.766 & 70 & 82 \\
& Modeling & 20 & 77.90 & 4.644 & 70 & 86 \\
& Mind Mapping & 22 & 78.18 & 5.114 & 68 & 85 \\
& Hybrid Learning & 15 & 73.73 & 3.807 & 67 & 80 \\
& Total & 75 & 76.75 & 4.673 & 67 & 86 \\
\hline Vocal Exercise Score & e-Learning & 18 & 75.89 & 3.376 & 72 & 82 \\
& Modeling & 20 & 74.05 & 4.685 & 65 & 84 \\
& Mind Mapping & 22 & 77.14 & 4.190 & 68 & 83 \\
& Hybrid Learning & 15 & 74.53 & 2.615 & 70 & 80 \\
& Total & 75 & 75.49 & 4.015 & 65 & 84 \\
\hline
\end{tabular}

Table 2. Statistic for Data Description of Post-Treatment

\begin{tabular}{llccccc}
\hline \multicolumn{1}{c}{ Variable } & \multicolumn{1}{c}{ Class } & n & Mean & SD & Min & Max \\
\hline Total Score & e-Learning & 18 & 79.22 & 4.319 & 73 & 86 \\
& Modeling & 20 & 82.35 & 3.801 & 76 & 89 \\
& Mind Mapping & 22 & 83.91 & 4.790 & 76 & 90 \\
& Hybrid Learning & 15 & 83.80 & 4.313 & 76 & 90 \\
& Total & 75 & 82.35 & 4.643 & 73 & 90 \\
\hline Fluency Score & e-Learning & 18 & 79.28 & 4.268 & 73 & 86 \\
& Modeling & 20 & 81.55 & 4.696 & 72 & 89 \\
& Mind Mapping & 22 & 84.59 & 4.553 & 73 & 90 \\
& Hybrid Learning & 15 & 84.20 & 4.229 & 76 & 90 \\
& Total & 75 & 82.43 & 4.875 & 72 & 90 \\
\hline Vocal Exercise Score & e-Learning & 18 & 79.22 & 3.859 & 73 & 85 \\
& Modeling & 20 & 81.45 & 4.559 & 73 & 89 \\
& Mind Mapping & 22 & 79.32 & 3.847 & 72 & 86 \\
& Hybrid Learning & 15 & 82.60 & 2.995 & 76 & 87 \\
& Total & 75 & 80.52 & 4.075 & 72 & 89 \\
\hline
\end{tabular}


The mastery of the material can be regarded independently on learning materials and or facilitated by the lecturers. Meanwhile, the indicators of fluency and vocal processing were not written explicitly in the material. The students must learn by their own with continuous practice to achieve fluency and good vocal. This is in accordance with the principle of the personal growth model (Irwansyah, Nurgiyantoro, \& Tou, 2017) that the success of this learning really depends on the individual concerned.

Prerequisite Test Analysis

The normality test of the initial and final test data in this study used the Kolmogorov-Smirnov $\mathrm{Z}$ test with the assistance of SPSS software (Santosa, 2016). The results of the analysis are summarized in Table 3, which shows that all research data have a normal distribution at the significance level of $p>0.05$.

The homogeneity test used Bartllet Test which produced F (Levene's Test for Equality of Variances). The results of the analysis are summarized in Table 4. The homogeneity test results showed that all data were homogeneous with $\mathrm{p}>0.05$.

The effects of several learning models on the escalation in total score, fluency, and the vocal exercise were analyzed using the one-way Anova. This analysis resulted in descriptive statistics presented in Table 5.

Table 3. Results of Data Normality Test

\begin{tabular}{clccc}
\hline \multirow{2}{*}{ No. } & \multicolumn{1}{|}{ Tested Data } & \multicolumn{2}{c}{ Kolmogorov-Smirnov (KS) } & \multirow{2}{*}{ Explanation } \\
\cline { 3 - 4 } & & Statistic & Sig. $(\mathbf{p})$ & \\
\hline 1. & Escalation $(\%)$ Total Score & 1.104 & 0.175 & Normal \\
2. & Escalation (\%) Fluency Score & 1.119 & 0.164 & Normal \\
3. & Escalation $(\%)$ Vocal Exercise Score & 0.954 & 0.323 & Normal \\
\hline
\end{tabular}

Table 4. Reseults of Homogeneity Test with Bartllet Test

\begin{tabular}{|c|c|c|c|c|}
\hline \multirow{2}{*}{ No. } & \multirow{2}{*}{ Tested Data } & \multirow{2}{*}{ df } & \multicolumn{2}{|c|}{ Levene's Test for Equality of Variances } \\
\hline & & & $\mathbf{F}$ & p (sig.) \\
\hline 1. & Escalation (\%)Total Score & $3: 71$ & 1.940 & $\left.0.131^{*}\right)$ \\
\hline 2. & Escalation (\%) Fluency Score & $3: 71$ & 0.867 & $0.462^{*)}$ \\
\hline 3. & Escalation (\%) Vocal Exercise Score & $3: 71$ & 2.514 & $\left.0.065^{*}\right)$ \\
\hline
\end{tabular}

Table 5. Descriptive Statistic on Granul Evaluation

\begin{tabular}{llcccc}
\hline \multicolumn{1}{c}{ Variable } & \multicolumn{1}{c}{ Class } & n & Mean \pm SD & Min & Max \\
\hline Escalation (\%)Total & e-Learning & 18 & $4.10 \pm 2.44$ & 1.19 & 8.82 \\
Score & Modeling & 20 & $5.58 \pm 2.94$ & 1.33 & 12.16 \\
& Mind Mapping & 22 & $3.54 \pm 2.06$ & 1.14 & 7.04 \\
& Hybrid Learning & 15 & $11.8 \pm 3.70$ & 4.88 & 17.33 \\
& Total & 75 & $5.83 \pm 4.05$ & 1.14 & 17.33 \\
\hline Escalation (\%) & e-Learning & 18 & $4.00 \pm 1.98$ & 1.23 & 8.86 \\
Fluency Score & Modeling & 20 & $4.74 \pm 3.15$ & 0.00 & 13.51 \\
& Mind Mapping & 22 & $8.31 \pm 2.92$ & 2.44 & 12.82 \\
& Hybrid Learning & 15 & $14.23 \pm 2.61$ & 9.59 & 19.44 \\
& Total & 75 & $7.51 \pm 4.64$ & 0.00 & 19.44 \\
\hline Escalation (\%) & e-Learning & 18 & $4.39 \pm 2.15$ & 1.32 & 9.21 \\
Vocal Exercise & Modeling & 20 & $10.09 \pm 3.33$ & 5.33 & 18.31 \\
Score & Mind Mapping & 22 & $2.88 \pm 2.07$ & 0.00 & 8.82 \\
& Hybrid Learning & 15 & $10.85 \pm 3.00$ & 7.50 & 17.57 \\
& Total & 75 & $6.76 \pm 4.36$ & 0.00 & 18.31 \\
\hline
\end{tabular}


The data analysis with computer software resulted in Anova tables, as summarized briefly in Table 6 . The summary of the one-way Anova table above can be described as follows. There is a significant difference in the effectiveness of escalation total score among the treatments of the learning models. This was showed by $F_{\text {count }}$ of 28.867 with $\mathrm{p}=0.000$. According to the average effectiveness, the highest increase was in the hybrid learning model with
$11.58 \%$; followed by modeling (5.58\%); elearning $(4.10 \%)$; and mind mapping $(3.54 \%)$. The mean score is visually presented in the histogram (Figure 2).

Based on the analysis results with the one-way Anova, there were significant differences among the learning models. Therefore, the analysis was continued with a post-hoc test with the LSD (Least Significant Differences). The results of the analysis are summarized in Table 7.

Table 6. Results of Oneway Anova, Granul Evaluation

\begin{tabular}{|c|c|c|c|c|c|c|}
\hline Data & Source & $\begin{array}{l}\text { Sum of } \\
\text { Square }\end{array}$ & df & $\begin{array}{c}\text { Mean } \\
\text { Square }\end{array}$ & $\mathbf{F}$ & Sig. (p) \\
\hline Escalation & Between & 667.555 & 3 & 222.518 & 28.867 & 0.000 \\
\hline \multirow[t]{3}{*}{$(\%)$ Total Score } & Groups & 547.297 & 71 & 7.708 & & \\
\hline & Within Groups & 1214.852 & 74 & & & \\
\hline & Total & & & & & \\
\hline Escalation (\%) & Between & 1065.954 & 3 & 355.318 & 47.599 & 0.000 \\
\hline \multirow[t]{3}{*}{ Fluency Score } & Groups & 530.005 & 71 & 7.465 & & \\
\hline & Within Groups & 1595.959 & 74 & & & \\
\hline & Total & & & & & \\
\hline Escalation (\%) & Between & 904.675 & 3 & 301.558 & 42.368 & 0.000 \\
\hline Vocal Exercise & Groups & 505.349 & 71 & 7.118 & & \\
\hline Score & $\begin{array}{l}\text { Within Groups } \\
\text { Total }\end{array}$ & 1410.024 & 74 & & & \\
\hline
\end{tabular}

Table 7. Results of post-hoc test with the LSD

\begin{tabular}{lccc}
\hline \multicolumn{1}{c}{ Differences among: } & Mean Difference & Sig. $(\mathbf{p})$ & Explanation \\
\hline e-Learning $><$ Modeling & -1.4771 & 0.106 & Not Significant \\
e-Learning $><$ Mind Mapping & 0.5631 & 0.525 & Not Significant \\
e-Learning $><$ Hybrid Learning & -7.4846 & 0.000 & Significant \\
Modeling $><$ Mind Mapping & 2.0401 & 0.020 & Significant \\
Modeling $><$ Hybrid Learning & -6.0075 & 0.000 & Significant \\
Mind Mapping $><$ Hybrid Learning & -8.0476 & 0.000 & Significant \\
\hline
\end{tabular}

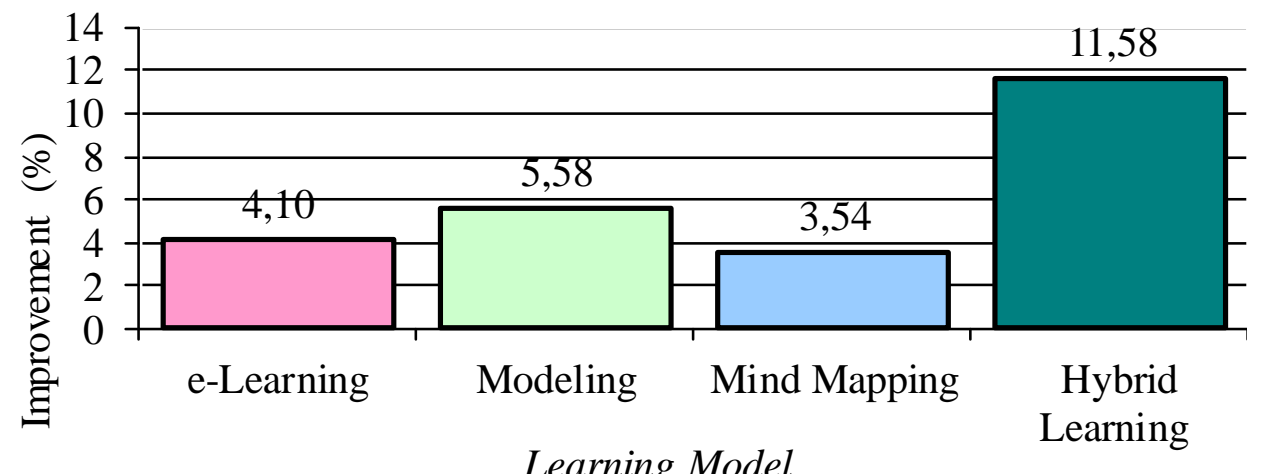

Learning Model

Figure 2. The Effectiveness of Escalation Total Score among the Treatments using the Learning Models 
There is a significant difference in the effectiveness of the escalation of fluency scores among the treatments of the learning models. This is shown by $F_{\text {count }}$ 47.599 with $p=0.000$. Based on the mean score, the highest increase is in the hybrid learning model with $14.23 \%$; followed by mind mappling (8.31\%); modeling $(4.74 \%)$ and e-learning $(4.00 \%)$. The mean is visually presented in the histogram (Figure 3).

The results of the analysis with the one-way Anova revealed that there were significant differences in the fluency indicators. Thus, the analysis was continued with a post-hoc test using the LSD (Least Significant Differences). The results of the analysis are summarized in Table 8.
There are significant differences in the effectiveness of the escalation the score in vocal among the treatments of the learning model. This is shown by $\mathrm{F}_{\text {count }}$ of 42.368 with $\mathrm{p}=0.000$. Based on the mean scores, the highest increase in the learning model is hybrid learning with $10.85 \%$; followed by modeling (10.09\%); elearning (4.39) and mind mappling $(2.88 \%)$. The mean is visually presented in the histogram (Figure 4).

The results of the analysis with oneway ANOVA revealed that there is a significant difference in vocal performance. Therefore, the analysis was continued with a post-hoc test using the LSD (Least Significant Differences). The results of the analysis are summarized in Table 9.

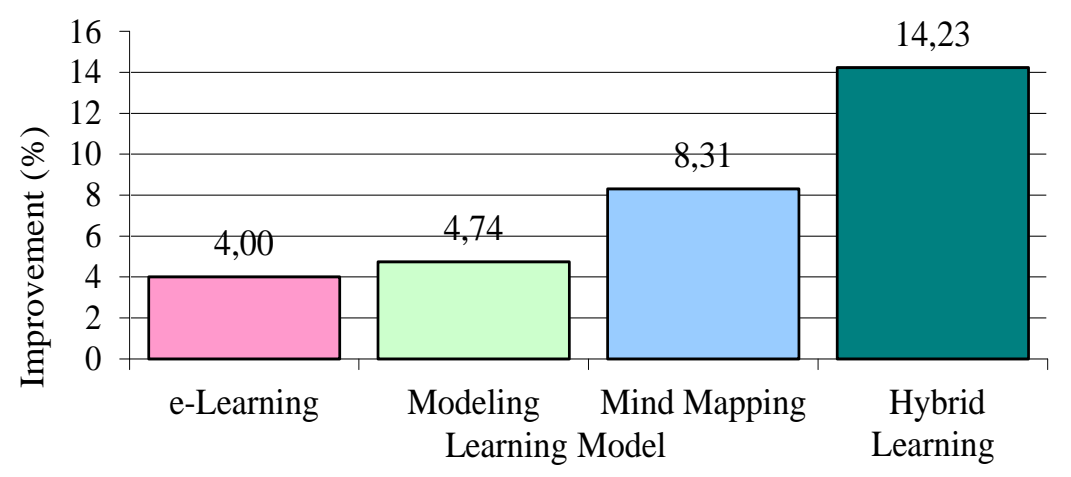

Figure 3. The Effectiveness of Fluency Score Escalation among the Learning Models

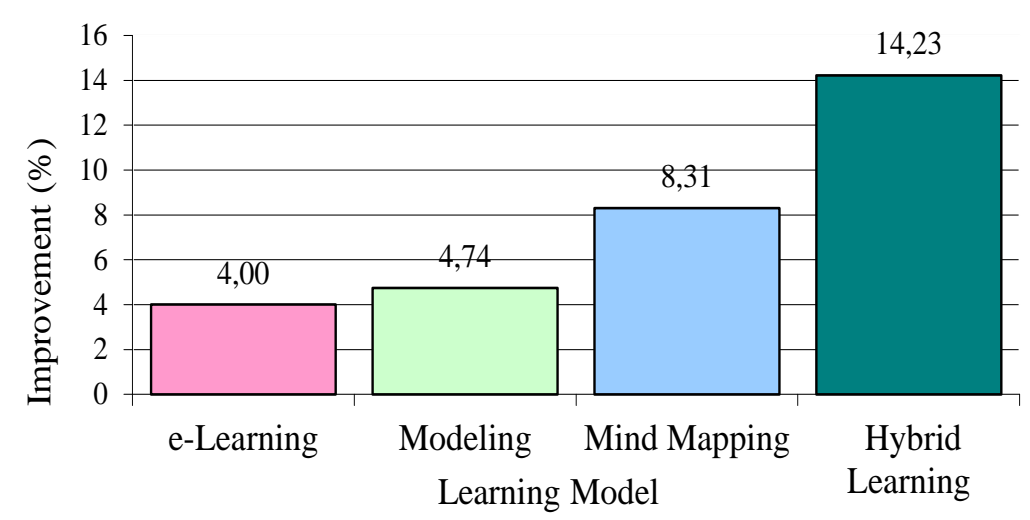

Figure 4. The Effectiveness of Score Escalation on Vocal Excercise among the Learning Models 
Table 8. Results of Post-hoc Test Using LSD

\begin{tabular}{lccc}
\hline \multicolumn{1}{c}{ Differences among: } & Mean Difference & Sig. $(\mathbf{p})$ & Explanation \\
\hline e-Learning $><$ Modeling & -0.7356 & 0.410 & Not Significant \\
e-Learning $><$ Mind Mapping & -4.3010 & 0.000 & Significant \\
e-Learning $><$ Hybrid Learning & -10.2256 & 0.000 & Significant \\
Modeling $><$ Mind Mapping & -3.5655 & 0.000 & Significant \\
Modeling $><$ Hybrid Learning & -9.4900 & 0.000 & Significant \\
Mind Mapping $><$ Hybrid Learning & -5.9245 & 0.000 & Significant \\
\hline
\end{tabular}

Table 9. Results of Post-Hoc Test Using LSD

\begin{tabular}{lccc}
\hline \multicolumn{1}{c}{ Differences: } & Mean Difference & Sig. $(\mathbf{p})$ & Keterangan \\
\hline e-Learning $><$ Modeling & -5.6927 & 0.000 & Significant \\
e-Learning $><$ Mind Mapping & 1.5133 & 0.079 & Not Significant \\
e-Learning $><$ Hybrid Learning & -6.4607 & 0.000 & Significant \\
Modeling $><$ Mind Mapping & 5.6927 & 0.000 & Significant \\
Modeling $><$ Hybrid Learning & 7.2060 & 0.000 & Significant \\
Mind Mapping $><$ Hybrid Learning & -0.7680 & 0.402 & Not Significant \\
\hline
\end{tabular}

\section{Discussion}

The experimental model of this study is the nonequivalent group pretestposttest design. Four parallel classes were given treatment with several different learning models. Before the treatment, the students were tested using a practice test and then they were given treatment with one of the learning models and at the end of the treatment a post-test was administered. There were four learning models implemented in this study, namely modeling, mind mapping, e-learning, and hybrid learning. The results in Tables 1 and 2 show the differences in outcome scores (mean, minimum score, and maximum score). The scores show an increase of the students' learning outcome after they were taught with one learning model. In other words, the tables show the impact of the learning model. Before the treatment, pranatacara lectures were held with the conventional method, but in this study, the teaching process was done through one of the aforementioned learning models. The teaching process with one learning model was conducted systematically according to the characteristics (syntax) of each learning model (Kintu, Zhu, \& Kagambe, 2017).
The learning activities with the systematic syntax resulted in some improvement in the mean score, as well as the minimum, and the maximum score in the class.

The total scores for pranatacara lecture consists of fluency and vocal exercise. Both aspects from each learning model increased (mean, minimum and maximum scores). However, the increase showed some dissimilarities seen from score indicators and each model. This indicates that there are, first, some effects or contribution of each learning model towards skills building to be a pranatacara, in terms of fluency and vocal exercise. Comprehensively, the speech fluency and vocal exercise got better due to the use of certain learning models. Second, there are some effect or contribution of each learning model towards skill development of a pranatacara in the form of fluency, and vocal were different. Third, there are differences as a result of the effect of learning model that needs to be tested for its effectiveness.

The effect of the learning models on the total score of fluency and vocal expercise is analyzed by using the oneway Anova. This analysis requires 
prerequisites of normally distributed data and homogeneous intergroup variances. The results of the initial and final test data using the Kolmogorov-Smirnov $\mathrm{Z}$ test on the total score of normal distribution (score 1.104 with p: 0.175> 0.05) show that the fluency score was normally distributed (score 1.119 with p: 0.164> 0.05 ), and the vocal was also normally distributed (score 0.954 with p: 0.323> 0.05). The data meet the requirements for the one-way Anova test. By using Bartllet Test, intergroup variance, the researcher found that the data were homogeneous, including the total score (F: 1940 with p: $0.131>0.05)$, the score of fluency (F: 0.867 with p: $0.462>0.05)$, and the vocal exercise score (F: 2.514 with $\mathrm{p}$ 0.065> 0.05). This means that intergroup variances were eligible for the one-way Anova test. Thus, the data of this study meet the requirements for the one-way Anova test.

The results of the one-way Anova test (Table 6) show that (a) there was a significant difference in the effectiveness of the the lecture models in increasing the total score, with $\mathrm{F}_{\text {count }}$ of 28.867 with $\mathrm{p}$ : 0.000 , (b) there was a significant difference in the effectiveness of the lecture model with $\mathrm{F}_{\text {count }}$ of 47.599 with $\mathrm{p}$ : 0.000 , (c) there was a significant difference in the effectiveness of the increasing vocal exercise between the treatment of lecture models with $\mathrm{F}_{\text {count }}$ : 42.368 with p: 0.000 . These results show that, in general, the hybrid learning model are significantly different from other models. Meanwhile, e-learning with model, and e-learning with mind mapping were not significantly different from prerequisite learning (Table 7). This shows that the hybrid learning model is the most effective model of teaching Pranatacara than other models. The further explanation of the effectiveness of the lecturing model on the total score for fluency, and vocal exercise as follows.

The dominance of the hybrid learning model over other learning models is also shown by the effectiveness of hybrid learning on fluency (Table 8) and vocal processing (Table 9). It is not significantly different from modeling only in vocal learning. This shows that (1) hybrid learning is the most effective model for teaching pranatacara for fluency and and ( 2) hybrid learning and modeling are equally effective for vocal exercise learning because both have equal opportunities for face-to-face trainings.

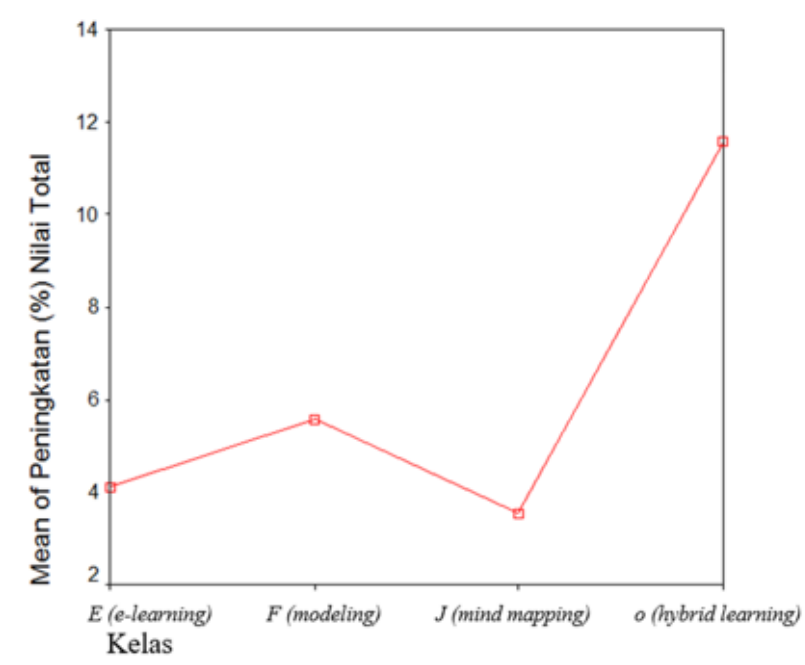

Figure 5. Average Increase in Total Score

The hybrid learning model is the most effective model in lecturing courses (11.58\%) (Figure 5). In addition, the increase in the score of the effectiveness of the hybrid learning model on the total score of 17.33. i.e the fluency of 19.44 . and the vocal exercise of 17.57. It also indicates that pranatacara lecture gets the most successful accomplishment when using a hybrid learning model. Hybrid learning had the highest contribution to the total score (performance of pranatacara practices) compared to the lecture with three other models (modeling, mind mapping, and e-learning). Hybrid learning also had the highest contribution to the score of fluency. In general, this is reasonable because hybrid learning provides learning opportunities at all times comprehensively (including class meetings) to students so that hybrid 
learning can improve learning outcomes (Kintu, Zhu, \& Kagambe, 2017:14) and give a good effect on learning abilities (Khan, 2016).

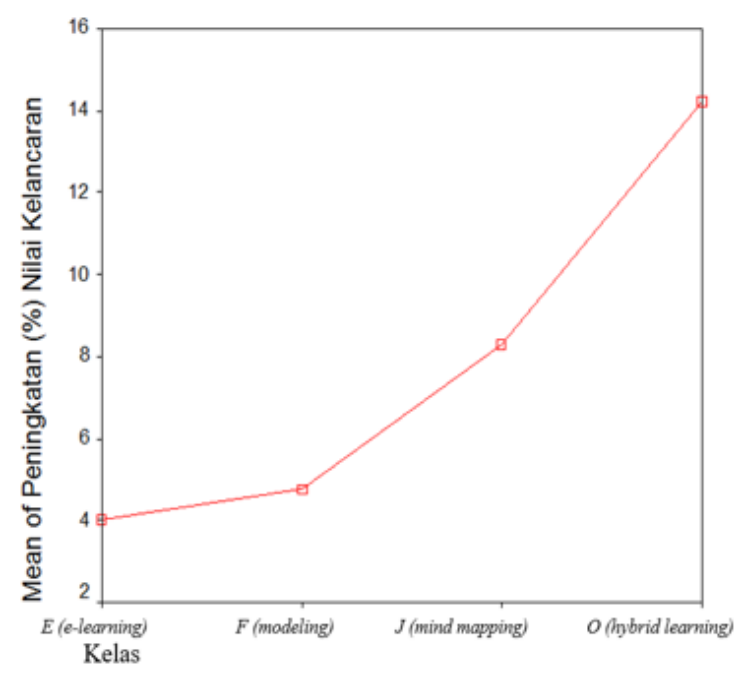

\section{Figure 6. Average Increase in the Fluency Score}

In the total score of fluency, hybrid learning had the highest effectiveness score. The modeling of vocal training was the only aspect above hybrid learning (Table 5). In details, the opportunity to learn vocal processing was under the modeling lectures. In modeling, the students can learn directly from the model, and they also receive direct correction, demands, and suggestions. Meanwhile, in hybrid learning, the vocal practice is experienced only from existing mimics on the Internet, without any criticism and correction by the lecturer. The students obtained only feedbacks during class meetings, which means there is a delay that can affect reduction of students' ability.

The advantages of the hybrid learning model are affected by its characteristics (Kintu, Zhu, \& Kagambe, 2017). The first characteristics include (a) the material accessible anywhere and anytime via the Internet, (b) the sufficient verbal text materials in hybrid learning, (c) pranatacara visualization in various photos, (d) the sample expressions used in pranatacara, (e) the samples of audio visual (video) procedures, (f) the students being able to directly ask questions to get solutions to problems, (g) the students being able to share their ideas through discussion forums (Patil, 2018: 26), (h) the students being able to learn based on their interests (without any particular order) because all materials are available in the Internet. The second characteristic is that the students can also learn using the classical method with direct guidance from the lecturers. The advantages of classical lectures are that the students have (a) the opportunity to have more discussion sessions during classical meetings, (b) direct examples (imitating) from lecturers, (c) direct facilitation from lecturers, (d) feedback in the forms of criticism, advice, inputs, and reflection. The third characteristic is that by using hybrid learning, the students (a) can learn repeatedly (drill system), and (b) obtain quick responses to problems without any delay to learn the next material, and that (c) hybrid learning also attracts attention and increases learning motivation and competency mastery (Swain \& Swain, 2017; Ceylan \& Kesici, 2017).

Strong motivation plays a crucial role to improve learning outcomes. Syntax or learning characteristics with hybrid learning provides benefits for students and lecturers in the learning process (Eshreteh \& Siaj, 2017; Kintu, Zhu, \& Kagambe, 2017), in this case, pranatacara learning. For lecturers and students, the hybrid learning model is considered as an appropriate learning model (especially, in this information technology era) due to its flexibility and effectiveness, and it stimulates students to become active learners. It also provides a positive effect on the improvement of language learning competencies with better learning experience (Eshreteh \& Siaj, 2017; Patil, 2018). This is supported by Eshreteh and Siaj's (2017) research which found that 
hybrid learning showed a significant effect on the career development of the students of the English Department, Hebron University. This is in line with this study where the practice of pranatacara lectures contributes positively to the students' ability to develop their careers into a professional pranatacara. Wichadee (2013) also points out that the hybrid learning model can improve the effectiveness and efficiency of Englishlanguage practical learning in Thailand. This is also in accordance with the results of the research by Souzanzan \& Bagheri (2017) which reported that the hybrid learning model can improve speaking skills. For a pranatacara, the main asset is the ability to process Javanese language. Thus, the study by Wichadee as well as Souzanzan and Bagheri shares similar results with this study.

The lecturing process with modeling contributed to a total score of $5.58 \%$. This is the second biggest portion after hybrid learning. For fluency, modeling ranked third $(4.74 \%)$ and it ranked second on vocal processing $(10.09 \%)$. Increasing the score of modeling to the total score was in the second position, with a score of 12.16. The fluency mastery was ranked second as well with a score of 13.51 after hybrid learning. Meanwhile, the increase in the score of the vocal exercise by treating modeling lectures ranked first, with the score of 18.31, which shows that modeling has a high effectiveness after hybrid learning. Even, modeling $(10.09 \%)$ has a high contribution to vocal learning compared to hybrid learning (10.85\%). The highest increase in maximal score of vocal exercise is also affected by modeling (18.31). This is supported by the characteristics (syantax) of the lecturing process with modeling.

The teaching of pranatacara through modeling is effective because (1) the students can directly observe, appreciate, imitate, demonstrate, and explain the model or lecturers (Salisu \& Rmson, 2014), and then they can develop the practice according to the model examples (lecturer); (2) if there is a problem in terms of the procedure, the lecturer can immediately provide a solution. Modeling provides accurate and very useful problem solving for students (Salisu \& Ransmom, 2014). When student practice has ended, lecturers can immediately provide responses, evaluations, and improvements. Such kind of syntax by Salisu \& Ransom (2014) is called task and performance modeling. This kind of modeling can enhance the student skills in practising pranatacara. The highest contribution to modeling is vocal exercise.

In modeling learning, the students can perform what is called as Triple $\mathrm{N}$, namely nonton (watching), niteni (paying attention), nirokake (imitating). Nonton is to see examples or models of pranatacara presented by lecturers (models). In this case, the lecturer also has a profession as a professional pranatacara since 1987. Niteni is paying attention and understanding to become the input of practical knowledge for students. For the practice of pranatacara, the students must be kandel (highly determined), kendel (brave) bandel (highly persevered), ngandel (believe), nekad (courageous) in their efforts (Dewantara, 2013). Ngandel means to believe, both to believe in the lecturer and the knowledge (imitated) and to believe in himself (confident) for his abilities. Kandel means having determination. This means that students have the determination to progress in learning process. Kendel means having a brave soul to practice being a guide. Bandel means to hold high-persevarance, striving to achieve success.

Furthermore, to become a professional pranatacara, according to the researchers' observations and experience, the students must have $4 \mathrm{~T}$, i.e niat (intention), tekad (determination), ragat (cost), nekat (courage). Niat means the initial desire; it is the goals and expectations that will be achieved to become a professional pranatacara. Tekad 
is the willingness to develop, for which the students need to devote their minds and energy to learning to become a professional pranatacara. Ragat means cost since becoming a professional guide, costs are needed, such as for buying books, recording audio and audio visuals, courses, or internships. Nekad means courageous because a professional pranatacara needs courage to practice at a real wedding ceremony in order to establish partnerships with venues and vendors. Venue is a place for bridal ceremony organizers such as hotels, meeting houses, and auditoriums. There are various kinds of vendors including wedding packages, wedding organizers, wedding dresses, decorations, and entertainment such as traditional music and modern music.

Tri $N$ (three n's) can be achieved by modeling whers the lecturer gives direct or indirect examples. An example is directly given by the lecturer to students during classical meetings. Indirect examples are given through audio or audio visual recordings. Meanwhile, in the direct examples, the students can imitate the speech from the model or vice versa - the model can guide students' speech. Students get corrections from their practice directly by the lecturer. In this way, they can learn progressively. If there are problems, they can get an immediate solution directly so that the problem does not interfere the pace of learning.

The third order of model effectiveness in terms of total score is elearning $(4.10 \%)$. In terms of the effect on vocal exercise, e-learning ranked third $(4.49 \%)$. In terms of fluency, it ranked fourth $(4.00 \%)$. The increase in the score of e-learning towards the total score is in the third place, with the score of 8.82. the score of fluency in the fourth order with a score of 8.86 and the score of the vocal exercise ranked fourth with a score of 9.21. These results indicate that e-learning does not provide high effectiveness (Khan, 2016) for lecture courses.

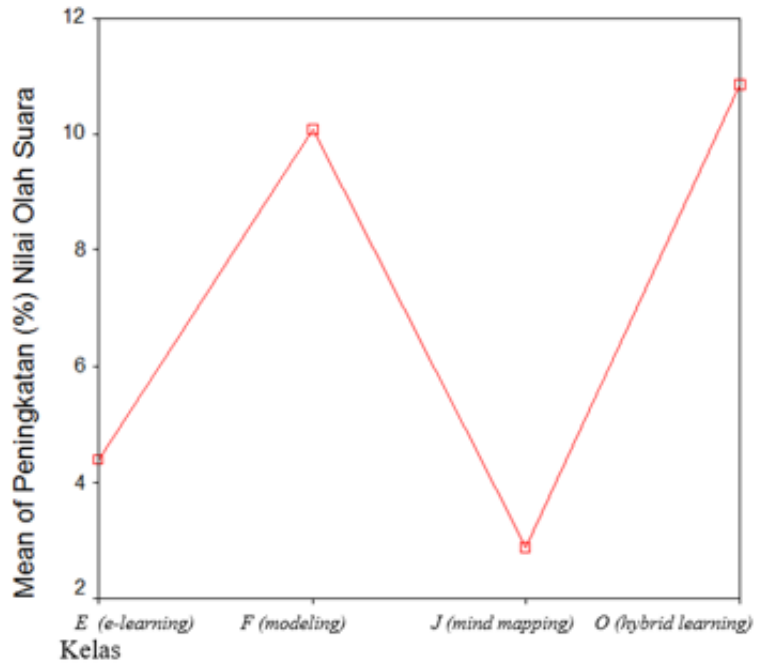

\section{Figure 7. Average Increase in Sound} Score

However, e-learning has several advantages in which (1) the students can learn independently anytime and anywhere via the Internet, (2) the students can also learn in full (based on their preference), (3) the solutions to problems can be obtained immediately; (4) the students can also obtain speech examples and/or performances. E-learning provides positive perceptions and advantages on technical issues as well as the development of cognitive abilities (Wu, et. al., 2017), but not the benefits of functional communicative problems in practical lectures (pranatacara) (Lubis, 2018), (5) e-learning (CALL: Computer Assisted Language Learning) can also reduce anxiety and psychological distress in learning (Shahi, 2016), (6) e-learning also pays attention to individual differences in learners (Patil, 2108). This means that learning styles are strongly affected by contexts such as abilities, and the opportunities of each individual.

In e-learning, the students do not get corrections directly from the lecturer for their speech training. It is the weakness of practical lecture using e-learning. In such a situation, the students are often delayed by the time to learn the procedure properly or asynchronously (Patil, 2018) as another weakness of learning through the Internet. 
As to vocal, it ranked third after hybrid learning and modeling. In hybrid learning and modeling, vocal can be monitored directly by the lecturer so that both models (hybrid learning and modeling) have high effectiveness in vocal exercise. Meanwhile, in e-learning, the students can learn through examples on the Internet without direct monitoring. It makes elearning ranked third after hybrid learning and modeling.

In terms of contribution to fluency, e-learning occupied the fourth (final) position. This is reasonable because elearning is not directly related or has a low causal relationship with fluency. Elearning cannot be a good tool for learning the speech fluency. E-learning also cannot be a means to monitor the smooth running of practice. E-learning or learning pranatacara through the Internet cannot control the students' fluency.

The effect of mind mapping on total scores $(3.54 \%)$ and vocal exercise $(2.88 \%)$ ranks fourth, and ranks second on fluency $(8.31 \%)$. The increase of the total score in the case of mind mapping was 7.04. Mind mapping ranked fourth after hybrid learning, modeling, and e-learning. The increase score of fluency as a result of using mind mapping models shows a score of 12.82 which is ranked third after hybrid learning and modeling. The increase in the score of vocal as a result of the mind mapping model shows a score of 8.82 . Mind mapping indicates significant effect on the score of fluency. Logically, mind mapping has a close (causal) relationship with fluency. That is why, it ranked second in the effect of mind mapping on fluency, which means mind mapping and fluency have a logical and direct relationship so mind mapping has a high contribution to fluency.

In mind mapping, the tudents made an immediate constituent of the program to be practiced. The subordinate elements or sub-events were arranged by students with mind mapping. Mind mapping also made the material have comprehensive structure not just words, and it also provided a clearer or easier way to find out complex topics (Vitulli \& Giles, 2016). In this way, the students are better at mastering the overall material (Kintu, Zhu, \& Kagambe, 2017), improving abilities or achievements (Ziyadi \& Surya, 2017). Similar results were also found by Jbeili study (2013) of level 6 children in Saudi Arabia, that mind mapping can improve students' academic abilities, and also a study by Blessing \& Olufunke (2015) in high school students at Ikere Local Government Area of Ekiti State in Nigeria which reported that main mapping can increase creativity, concepts or ideas, and memory.

The students have carried out the analysis so that they have mastered the subordinate elements better. In this area, they become fluent when speaking (pranatacara practice). The steps of mind mapping are the students (1) accept the main program as a pranatacara, (2) read various references related to the main method, (3) make the analysis of subordinate elements into sub-elements, (4) develop these elements into oral text, (5) practicing the speech using the developed text, and (6) do the pranatacara practice. In this way, the students have carried out a multi-level learning, from reading, understanding, analyzing, synthesizing, and developing speech texts so naturally they become fluent. This result is consistent with the research by Widiana \& Jampel (2016) with elementary school children of Bali which reported that syntax mind mapping can increase critical, creative, multiple intelligence; and achievement/ability, and that learning becomes fun. The research conducted by Yunus \& Chien (2016) on 25 vocational high schools in Malaysia showed that mind mapping increases creativity in writing. It is in line with mind mapping in the Pranatacara lecture that requires the ability to think critically in conducting a subordinate analysis.

The tendency of mind mapping to occupy the last place on total score and 
vocal exercise is reasonable because mind mapping lacks a close causal relationship with total score and vocal processing. Mind mapping scarcely has a direct relationship with the practice of pranatacara in total score and vocal exercise. The contribution of mind mapping to vocal exerecise ranked fourth with $2.88 \%$, which means that mind mapping contributes only $2.88 \%$ to vocal processing. This is reasonable because mind mapping does not provide vocal exercise. These contributions tend to be exploration or the student's own attempts. Because of the exploration as trial and error, there was a vocal exercise that was acceptable and some were not. The acceptable vocal exercise was only $2.88 \%$.

The indicators of acceptable vocal exercise are as follows. (1) The speech is clear and phonetically firmed. (2) It contains a tempo (fast and slow speech). (3) It is dynamic (high and low tone of speech). Tempo and dynamism in the Javanese vocal processing is called membat mentuling swara. (4) There are short pauses or lengths of speech. For lamba songs, the pause is per word or phrase, while for chanting songs the pause is per clause, sentence, or several sentences. (5) The vocal type is bass or baritone (Javanese: gandem ulem). (6) Javanese songs are adjusted to their conventions. (7) Vocal exercises are also adjusted to the context. In the atmosphere of joy and enthusiasm, aufoni vocal exercise is used. Meanwhile, in the emotion condition, the vocal of the kakofoni with a little hoarse is used. Happy and uplifting ceremonies include balangan gantal 'lempar sisih', miji dadi 'memecah telur (egg breaking)', ranu pada the bride washing the bridegroom's feet', and for sad moment, such as ngabekten 'devotion before the shower of the bride and groom' and sungkeman 'a sign of devotion and gratitude at the bride and groom meeting'.
Based on the discussion above, of the four learning models - modeling, mind mapping, e-learning, and hybrid learning models, the most superior and dominant is the hybrid learning model, followed by modeling and mind mapping models. Meanwhile, the least dominant is the elearning model.

\section{CONCLUSION}

Based on the research findings and discussion, some conslusions can be drawn as follows. (1) Hybrid learning is the most effective learning model for Pranatacara lectures. It gives the students broad opportunity to learn comprehensively based on their needs anytime and anywhere. The students also experienced the increase in their ability, as well as direct criticism, suggestions, judgments, guidance on classical learning and feedback facilitation (Internet). (2) The modeling model is the most suitable model for learning through examples. In this case, the students can do the Triple $N$, namely nonton (watching), niteni (paying attention), nirokake (imitating) of the model displayed by the lecturer.The students also obtain immediate corrections and guidance to improve their abilities (especially in vocal exercise). (3) The elearning model is not suitable for practical learning since it requires direct interaction between the students and the lecturers. (4) The mind mapping model gives a high contribution to fluency in communication because it provides the opportunity for students to develop their analytical skills on a topic (immediate constituent analysis) so that they gain better understanding of the materials of pranatacara and become more fluent in practicing it.

\section{ACKNOWLEDGMENT}

Our gratitude goes to four parallel classes of Pranatacara, the students of Javanese Language Education, Faculty of Languages and Arts, Universitas Negeri Yogyakarta. 


\section{REFERENCES}

Ahmadi, M. R. (2018). The use of technology in english language learning: A literatur review. International Journal of Research in English Education (IJREE), 3(2), 115-125. doi:10.29252/ijree.3.2.115.

Almaqtri, M. (2014). How effective is elearning in teaching english?: A case study. Journal of Education and Human Development, 3(2), 647-669.

Aydin, G., Baysan, S., \& Aydoğan, S. (2017). Perceptions in the mind maps of turkish children living in england at primary education level about their home country turkey and the world. International Journal of Languages' Education and Teaching, 5(4), 521-541.

Blessingn, O. O. \& Olufunke, B. T. O. (2015). Comparative effect of mastery learning and mind mapping approaches in improving secondary school students' learning outcomes in physics. Science Journal of Education 2015, 3(4), 78-84. doi:10.11648/j.sjedu.20150304.12.

Ceylan, V. K., \& Kesici, A. E. (2017). Effect of blended learning to academic achievement. Journal of Human Sciences, 14(1), 308-320. doi:10.14687/jhs.v14i1.4141.

Dewantara, K. H. (2013). Ki Hajar Dwantara: Pemikiran, konsepsi, keteladanan, sikap merdeka (Cetakan IV). Yogyakarta: Universitas Sarjanawiyata Tamansiswa bekerjasama dengan Majelis Luhur Persatuan Tamansiswa.

Eshreteh, K. M. \& Siaj, A. H. (2017). Attitudes of english-major students and teachers towards using blended learning in the english department at
Hebron University. International Journal Research in English Education, 2(4), 51-65. doi:10.29252/ijree.2.4.51.

Farindhni, D. A. (2018). Developing animation video media to enhance the learning motivation and democratic character of the 5 th grade students in primary school. Jurnal Pendidikan Karakter, III(2), 172186. doi:10.21831jpk. v8i2.21850.

Irwansyah, D., Nurgiyantoro, B., \& Tou, A. B. (2017). Teaching with literature: The needs of Indonesian Islamic Universities. International Journal of Applied Linguistics \& English Literature, 6(7), 169-179. doi:10.7575/aiac.ijalel.v.6n.7p.169.

Jbeili, I. M. A. (2013). The impact of digital mind maps on science achievement among sixth grade students in Saudi Arabia. Procedia Social and Behavioral Sciences, 103(2013), 1078-1087. doi:10.1016/j.sbspro.2013.10.435.

Khan, A. I. (2016). Effectiveness of elearning for the teaching of english: A study of comparative strategies. Advances in Language and Literary Studies, $\quad 7(3), \quad$ 125-135. doi:10.7575/aiac.alls.v.7n.3p.125.

Klimova, B. F. \& Kacetla, J. (2015). Hybrid learning and its current role in the teaching of foreign languages. Procedia-Social and Behavioral Sciences, 182(2015), 477-481. doi:10.1016/j.sbspro.2015.04.830.

Kintu, M. J., Zhu, C. H., \& Kagambe, E. (2017). Blanded learning effectiveness: The relationship between student characteristic, design features, and outcome. International Journal of Educational Technology in Higher Education, 
14(7), 1-20. doi:10.1186/s41239017-0043-4.

Li, J., Kay, R., \& Markovich, L. (2018). Student attitudes toward blended learning in adult literacy and basic skills college programs. Canadian Journal of Learning and Technology, 44(2), 1-36. doi:10.21432/cjlt27573.

Low, P. (2017) E-learning implementation in foundation english class: Learners' perspectives and leaPatilrning achievement. International Journal of Computer Theory and Engineering, 9(4), 285289.

doi:10.7763/IJCTE.2017.V9.1153.

Lubis, A. H. (2018). ICT integration in 21st-century Indonesian english language teaching: myths and realities. Cakrawala Pendidikan, 37(1), 11-21. doi:10.21831/cp.v37i1.16738

Muhson, A. (2016). Pedoman praktikum analisis statistik. Yogyakarta: Fakultas Ekonomi Universitas Negeri Yogyakarta.

Patil, R. S. (2018). E-learning technologies in english language teaching at tribal area. International Journal of Science, Engineering and Management (IJSEM), 3(2), 24-29.

Ramadhanti, D. \& Yanda, D. P. (2017). Understanding poetry through the use of cooperative learning model. Jurnal Cakrawala Pendidikan, 37(3), $\quad$ 436-446. doi:10.21831/cp.v38i3.20675.

Santosa, S. (2016). Panduan lengkap SPPS Versi 23. Jakarta: Elekmedia Computindo.
Salisu, A. \& Ramson, E. (2014). The role of modeling towards impacting quality education. International Letters of Social and Humanistic Sciences, 32, 54-61. doi:10.18052/www.scipress.com/ILS HS.32.54.

Shahi, M. A. J. (2016). The impact of elearning on improving Iranian EFL learners'language skills: Decreasing learning anxiety. Journal of Fundamental and Applied Sciences, 8(3), 261-275. doi: 10.4314/jfas.v8i3s.180.

Souzanzan, R. \& Bagheri, M.S. (2017). Hybrid learning: The impact of interacting through skype on Iranian learners' speaking ability. Information Technologies and Learning Tools, 58(2), 118- 128.

Swain, L. O. S. \& Swain, T. D. (2017). Language learning under classroom conditions during the transition to hybrid instruction: A case-study of student performance during the implementation of instructional technology. European Journal of Foreign Language Teaching, 2(3), 49-63. doi:10.5281/zenodo.1034563.

Vitulli, P. \& Giles, R. (2016). Mind mapping: Making connections with images and color. Delta Journal of Education, 6(2), 1-10.

Wichadee, S. (2013). Facilitating students' learning with hybrid instruction: A comparison among four learning styles. Electronic Journal of Research in Educational Psychology, 11(1), 99-116. doi:10.25115/ejrep.v11i29.1559.

Widiana, I. W. \& Jampel, I. N. (2016). Improving students' creative thinking and achievement through 
the implementation of multiple intelligence approach with mind mapping. International Journal of Evaluation and Research in Education (IJERE), 5(3), 246-254. doi:10.11591/ijere.v5i3.4546.

Wu, C-H., Chen, Chen, Y-S., Chen, T-C. (2017). An adaptive e-learning system for enhancing learning performance: Based on dynamic scaffolding theory. EURASIA Journal of Mathematics, Science and Technology Education, 14(3), 903913. doi:10.12973/ejmste/81061.
Yunus, M. Md. \& Chien, C. H. (2016). The use of mind mapping strategy in Malaysian University English Test (MUET) writing. Creative Education, 7(4), 619-626. doi:10.4236/ce.2016.74064.

Ziyadi, A. \& Surya, E. (2017). Use of model mind mapping of motivation to improve student achievementin math class materials integer $\mathrm{V}$ elementary school 200201 Padangsidimpuan State. International Journal of Sciences: Basic and Applied Research (IJSBAR), 34(3), 124-133. 